\title{
THE EXAMINATION OF SOCIAL CAPITAL IN HUNGARIAN RURAL COMMUNITIES: THE CASE OF BÁTYA VILLAGE
}

\author{
Zsuzsanna Kassai \\ assistant professor \\ Eötvös Loránd University, Faculty of Informatics, Budapest Co-Location Centre \\ E-mail: kassai@inf.elte.hu
}

\begin{abstract}
The term 'social capital' was first used in the international literature in the beginning of the $20^{\text {th }}$ century by Lyda Judson Hanifan, but it became widely known only in the 1990s and there is still no consensus on how to measure it. In the beginning of the paper a short review can be found concerning the different approaches, definitions and functions of social capital. Then an example for measuring method is presented through a Hungarian case study. In this part, some fundamental social characteristics of the population of Bátya village are examined.
\end{abstract}

Keywords: social capital, cooperation, general trust, strategic trust, sustainable development JEL: Q01, R00, R11, Z1

LCC: HM481-554, HM756-781

\section{Introduction}

'Smart communities are defined by the Canadian Federal Government (CFG) (2002) as those communities in which local leaders and stakeholders, by use of electronic networks and the Internet, are forming alliances and partnerships in order to innovate and extract new economic and social value.' (Stratigea, 2012, p.377.) In this definition, emphasis is on investments in human and social capital in support of sustainable community objectives and quality of life.

Gurstein (2014) also states that a smart community can significantly contribute to the increase in social capital in the region, since smart community can promote the use of information and communication technologies (ICTs) to engage with citizens to develop social capital and intellectual capital, and so they can make a better use of hard infrastructure (physical capital), reduce the usage of environmental capital and support the smart growth and sustainable economic development (Gurstein, 2014).

The popularity of social capital can be explained by the "wider recognition that economic development models have failed to explain why some areas appear to have been able to develop while others have not' (Lee et al., 2005, 270.p.). A wide range of literature (e.g. Füzér et al., 2005; Kis 2006a,b; Kulcsár, 2006; Tóth-Káposzta, 2013) proves that social capital has an essential role in sustainable rural development. Where social capital is weak, there are conflicting values and a lack of trust, which hinder any economic or social development activities. If there is a low level trust between the local actors the transactional and administrative costs of business activities are going to increase, which results in the loss of efficiency (Tóth-Jóna, 2012). Beside, social capital can make a significant contribution to poverty alleviation as well. Therefore, social capital has a great importance in smart communities.

The term social capital is going to be defined below. The definition of social capital can be examined from different approaches. It can be analysed from anthropological approach, which 
mainly focuses on the biological and psychological components of social capital. According to the representatives of this approach, trust and cooperation are basic human needs. As opposed to this point of view, the sociological approach put primarily norms and motivation in the centre of its research. The most important representatives of sociological approach are Pierre Bourdieu and James Samuel Coleman. The economic approach emphasises that cooperation and trust are very significant economic factors; they are among the most important sources of economic efficiency. Its most significant representative is Francis Fukuyama. The political approach brings into focus the examination of relations between social capital and democracy. This point of view stresses that the increase of social capital is essential in order to strengthen democracy, social solidarity and sustainable development (Skrabski-Kopp, 2008; Szakál, 2004).

Since the 1990s social capital has been given a number of different definitions (Fukuyama, 2001). On the basis of the concepts of the above mentioned Bourdieu (1986), Coleman (1988), Putnam $(1993,1995)$, Fukuyama $(1995,2002)$ the social capital is a mixture of relations, trust, civil social activity and norms regulating social behaviour. Because of the limitation of the length of this study, only the first three factors are examined.

In the literature three forms of trust are usually distinguished: the general, the strategic and the institutional trust. The general trust is felt towards people who are not known. It is based on empathy. The strategic trust as opposed to the previous form stems from experiences. Such trust can be felt towards relatives, friends, colleagues etc. (Havasi, 2009). Institutional trust is analysed only indirectly in this paper.

An important factor of sustainable rural development is the presence of an active 'social core' in the community (Gerencsér-Áldorfai, 2017; Oláh et al., 2012). If the settlement has a 'core' which unites and motivates the community, and to which people representing various interests and values can join, then this 'core' is a basic value of the settlement, which determines success as well. The 'core' of a community is a value which can turn into a strategically important resource by helping the mobilization of local economic and social resources. A fundamental indicator of an active community is the number of non-governmental organizations, since NGOs can contribute significantly to the development of local community, building of social capital and so to the strengthening cooperation among them (Kuti, 1996; Nárai, 2008, 2004; Putnam, 2000; Reisinger, 2012; Szakál, 2004). The role of NGOs in fostering social capital building is very important, since with low level of social capital, there is a lack of trust which can hinder any social or economic development activities in the settlement (Kis, 2006a,b; Ritter, 2014; Tóth and Jóna, 2012).

Local non-governmental organizations can activate the community members, and so can foster their integration into the local society (Kuti, 1996). According to Áldorfai et al. (2016), the characteristics of membership in NGOs may refer to the intensity of social participation and the strength of local communities. Besides, such organizations have a great importance from economic (e.g. contribution to GDP, employment, etc.) and development policy point of view and promote the appropriate operation of democracy (Reisinger, 2012). Thus, nongovernmental organizations can provide a better quality of life for community members. 


\section{Material and methods}

\section{The Study Area}

Bátya is a small village in Bács-Kiskun County in the Southern Great Plain Region (Fig. 1.).

The population number is around 2000 people. Bátya village faces serious demographic problems. Since the beginning of the $20^{\text {th }}$ century the population has been continuously decreasing. The main reasons for that is the natural decrease in population and the negative net migration rate (HCSO, 2015). In addition, the ageing index was $129 \%$ in 2011, so Bátya is an ageing village. Moreover, the educational level of the villagers is lower than the average educational level in Bács-Kiskun County. Therefore, it is not surprising that the unemployment rate in Bátya village ( $8 \%$ in 2011) is higher than county average value (5\% in 2011) (HCSO, 2011). Scientific evidence shows that the enhancement social capital can contribute to the solving of such demographic problems (Füzér et al., 2005).

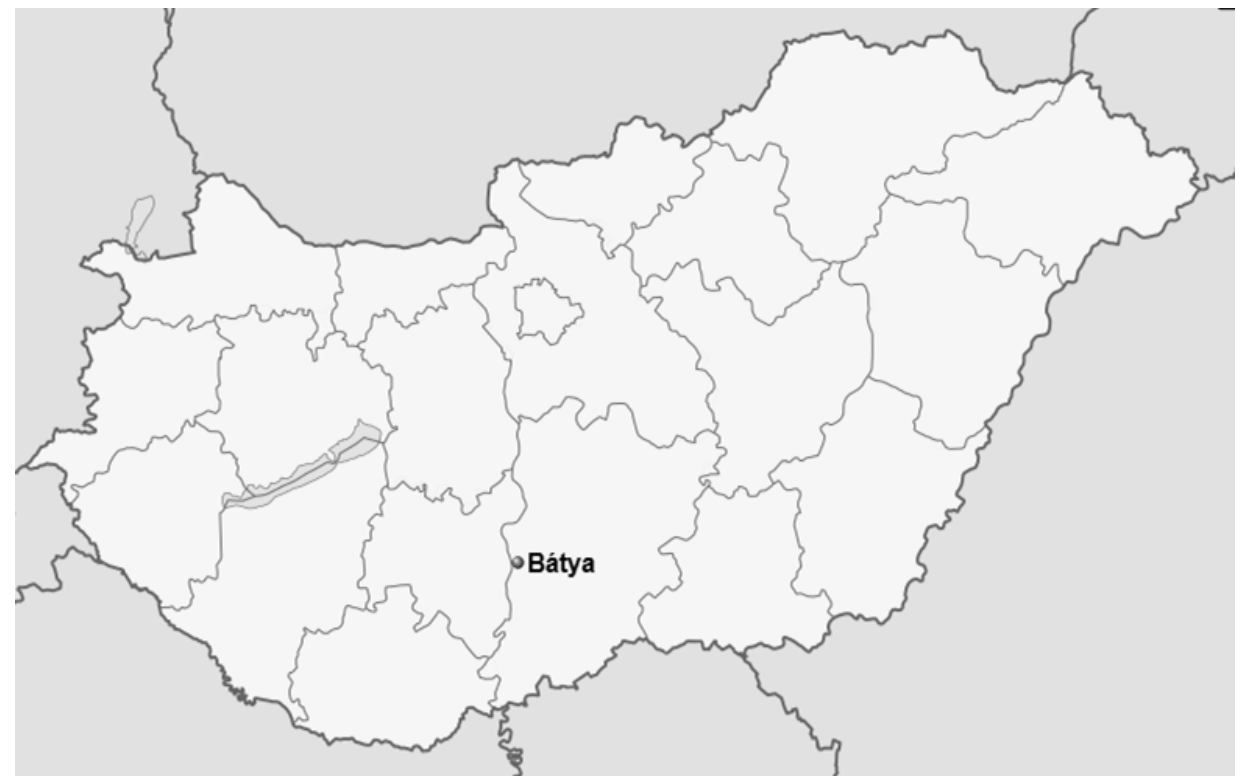

Figure 1. Location of Bátya village

Source: own editing based on questionnaire survey, 2017

This study is based on an extended primary data collection, since a questionnaire survey in 237 households of Bátya village (Fig. 1) were conducted and semi-structured interviews were made with the key actors of local rural development in the summer of 2016.

\section{The characteristics the sample}

In the questionnaire survey simple random sampling was used. The survey was territorially fully representative, while from demographic point of view only partially representative. In Bátya the sex ratio of the population was $48 \%$ male and $52 \%$ female in 2015 . In the questionnaire survey men were a bit underrepresented, since their ratio was $44 \%$. The main reason for that is the participation willingness in our survey of female inhabitants was higher.

In my survey the children (below 18years) were excluded. This is one of the reasons why the, the Youth were underrepresented in the sample, while the elder population was highly overrepresented (Table 1). Besides, the survey was done in the summer and many economically 
active person worked in agriculture were too busy to take part in the research, while others were on holiday.

Table 1. Age Distribution of the Population and Respondents

\begin{tabular}{|l|c|c|}
\hline & population & sample \\
\hline 0-19 years & $19 \%$ & $5 \%$ \\
\hline $\mathbf{2 0 - 3 9}$ years & $25 \%$ & $18 \%$ \\
\hline $\mathbf{4 0 - 5 9}$ years & $31 \%$ & $31 \%$ \\
\hline 60+ years & $25 \%$ & $46 \%$ \\
\hline
\end{tabular}

Source: own edition based on HCSO, 2015 and questionnaire survey, 2016

Because of the age structure of the population the marital status of the population and the sample also differed. The proportion of single was lower by $14 \%$ and the proportions of widowed and married were higher by $6 \%$ and $9 \%$ in the sample compared to population.

Since the children were excluded and the higher educated people showed a higher willingness to participate in the research, the proportion of non-educated was lower by $8 \%$, while the proportion of tertiary education attainment was higher by $9 \%$, compared to population.

Besides, semi-structured interviews were made with some local experts: Ilona Zsebics, the mayor; Csaba Fekete, the deputy mayor; Linda Noémi Bukros, the notary; and Zoltán Fehér, the retired associate professor from Eötvös József College.

\section{Methods}

General trust is examined with the help of two statements, which were contradictory: 1) 'Most people can be trusted.' 2) 'Most people would exploit you, if they could.' Strategic trust was also studied by the agreement with the following two statements: 1) 'Most friends can be trusted.' 2) 'Most friends/family members can be trusted.' To reveal the level of institutional trust, I assess the answers for the question whether who should be asked about important issues concerning the village and its community. After that two components of social activity are studied. First, the willingness to do voluntary work and second, the membership of social organization are examined.

Frequencies are calculated from the so gained primary data. The results are demonstrated with the help of graphs. The relations between trust of respondents and their demographic characteristics (sex, age, marital status and qualification) are studied by cross-tabulation analysis.

\section{Results}

First, the general trust level was examined. The research findings proved that general trust felt towards foreign people was quite unfavourable (see Figure 2.). It can be seen below that almost two-third of the respondents (64\%) does not agree with the statement that 'Most people can be trusted'. Only $35 \%$ stated that they could trust in foreign people, who they did not know and who could view things differently as they do.

The national general trust values are more favourable than the values in Bátya village. In the research of TÁRKI, called Economic Culture, 44\% of the Hungarian respondents stated that most people can be trusted. However, in Bátya village only $35 \%$ thought the same thing. So the general trust value is worse than the national average. 


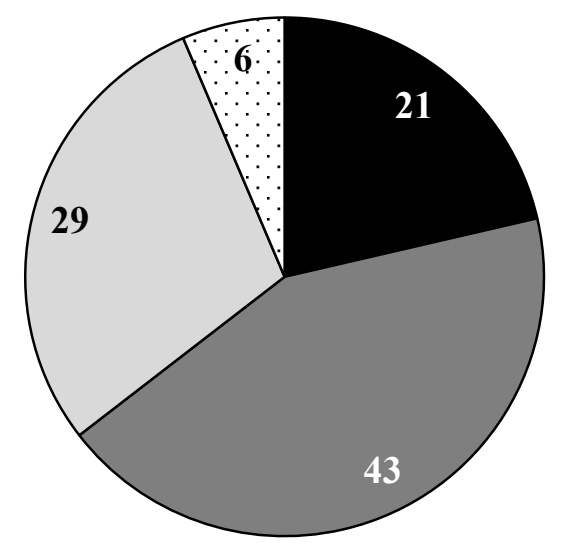

- strongly disagree

$\square$ disagree

$\square$ agree

$\square$ strongly agree

\section{Figure 2. General trust in Bátya village I. ('Most people can be trusted.') (\%)}

Source: own editing based on questionnaire survey, 2017

The results concerning general trust were checked by a contrary statement in the survey (see Figure 3.). It was examined how much the respondents agreed that 'Most people would exploit you, if they could'. Similar results were obtained to the previous findings, since $58 \%$ did not trust in foreign people, because they felt foreign people would have exploited them. Only twofifth of the respondents disagrees with this statement.

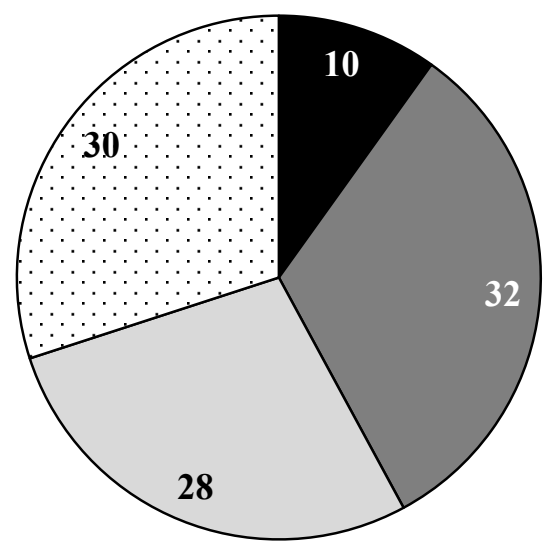

- strongly disagree

$\square$ disagree

$\square$ agree

$\square$ strongly agree

Figure 3. General trust in Bátya village II. ('Most people would exploit you, if they could.') (\%)

Source: own editing based on questionnaire survey, 2017

Based on the findings of cross-tabulation analysis, it can be established that the sex, the age, the marital status and the qualification of respondents do not significantly relate to the level of general trust based, since the Asymptotic Significance (2 Sided) for Pearson Chi-Square statistics were higher than 0.05 . They were: 0.338 for sex; 0.138 for marital status; 0.645 for age and 0.910 for qualification in case of the first statement, while 0.540 for sex; 0.450 for marital status; 0.670 for age and 0.620 for qualification in case of the second statement.

Although there was not significant relationship, it was found that mostly those respondents did not trust in foreign people who were retired or unemployed. Some of them had less empathic personality, while others gained some unpleasant experiences with foreign people concerning trust and so they could hardly trust in anybody. 
However, the strategic trust was much more favourable, much stronger than the general trust in the village. Especially, strategic trust felt towards family members was very high (see Fig. 4.). 94\% agreed with the statement 'Most family members can be trusted'. Only a few people (6\%) did not trust in their relatives. According to the findings of cross-tabulation analysis, these people are mainly those who had got divorced or disappointed in their spouse or relatives. The Asymptotic Significance (2 Sided) for Pearson Chi-Square statistic was 0.019 for marital status. The relationship was quite weak, the Cramer's V statistic was only 0.253 , which means the marital status of respondents has a small effect on trust felt towards family members. The Adjusted Residual was only in case of the divorced (+3.4) greater than +2 , which means there was significant relationship between the divorced respondents and disagreement with the statement of 'Most family members can be trusted'.

However, this analysis also revealed that similarly to general trust the sex, the age and the qualification of respondents did not influence significantly the trust felt towards family members, since the Asymptotic Significance (2 Sided) for Pearson Chi-Square statistics were higher than 0.05 ( 0.872 for sex; 0.073 for age and 0.061 for qualification).

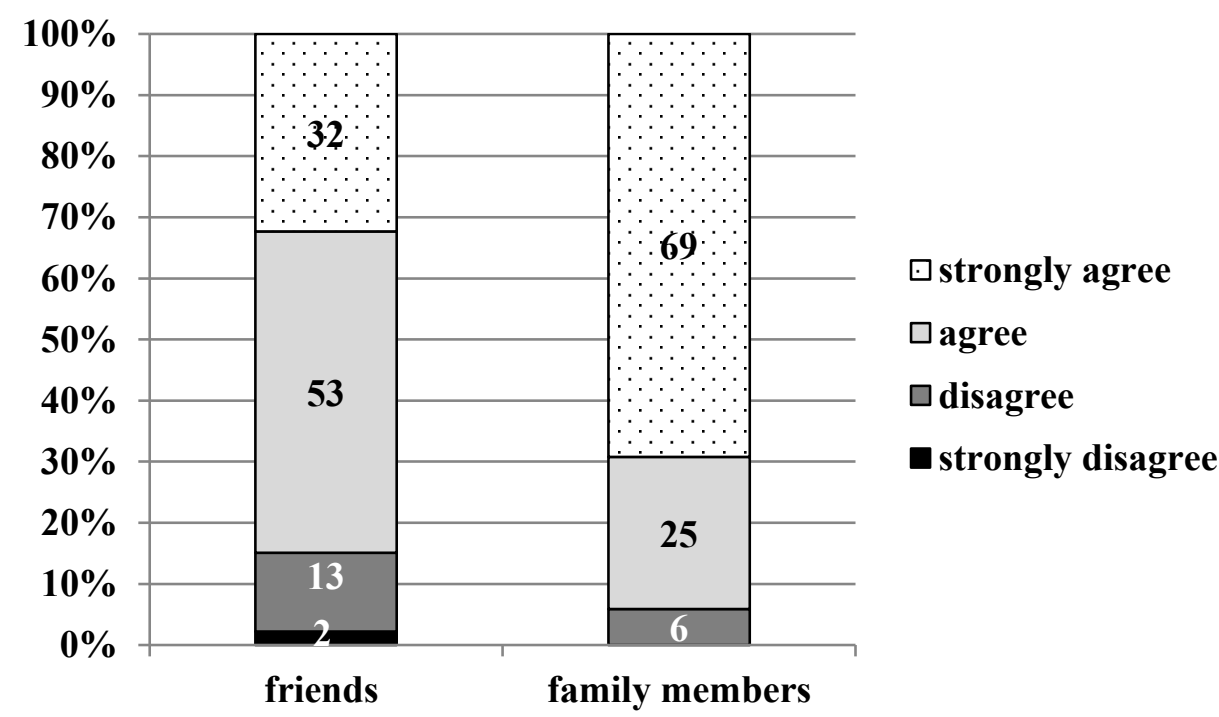

Figure 4. Strategic trust in Bátya village ('Most friends/family members can be trusted.') (\%)

Source: own editing based on questionnaire survey, 2017

It was found that the other component of strategic trust, the trust felt towards friends was also very high in Bátya village (see Figure 4.). The survey highlighted that $85 \%$ of the inhabitants trusted in their friends. Based on this fact it can be stated that the villagers are not isolated, even they are opened and friendly.

Based on cross-tabulation analysis the level of trust felt towards friends is not in significant relation with the demographic characteristics (the sex, the age or marital status and qualification) of respondents, so these factors did not influence meaningfully the strength of strategic trust. The Asymptotic Significance (2 Sided) for Pearson Chi-Square statistics were higher than 0.05 (0.086 for sex; 0.373 for marital status; 0.456 for age and 0.138 for qualification).

I also made attempt to map who can most significantly influence the public opinion in the village. To examine this issue, two questions were placed in the questionnaire survey: 1) In 
your opinion, who should be asked about the important issues concerning the village?; 2) Who do you talk to regularly?

It is also not surprising that staff members of the local government are the most frequently mentioned persons, since they are the best-know actors in the village. Most respondents said that the opinion of the mayor, Ilona Zsebics should be taken into account. The deputy mayor, Csaba Fekete was on the second place, the notary, Linda Noémi Bukros was on the fourth place and a local representative, József Mészáros was on the fifth place. There was only one academic person among the most popular people. He was Zoltán Fehér, the retired associate professor from Eötvös József College, who has conducted local historic and ethnographic researches for decades (Fig. 5.).

On the other hand, it is a quite unfavourable result that the proportion of those who do not know who should be asked about the important issues related to the village was quite high.

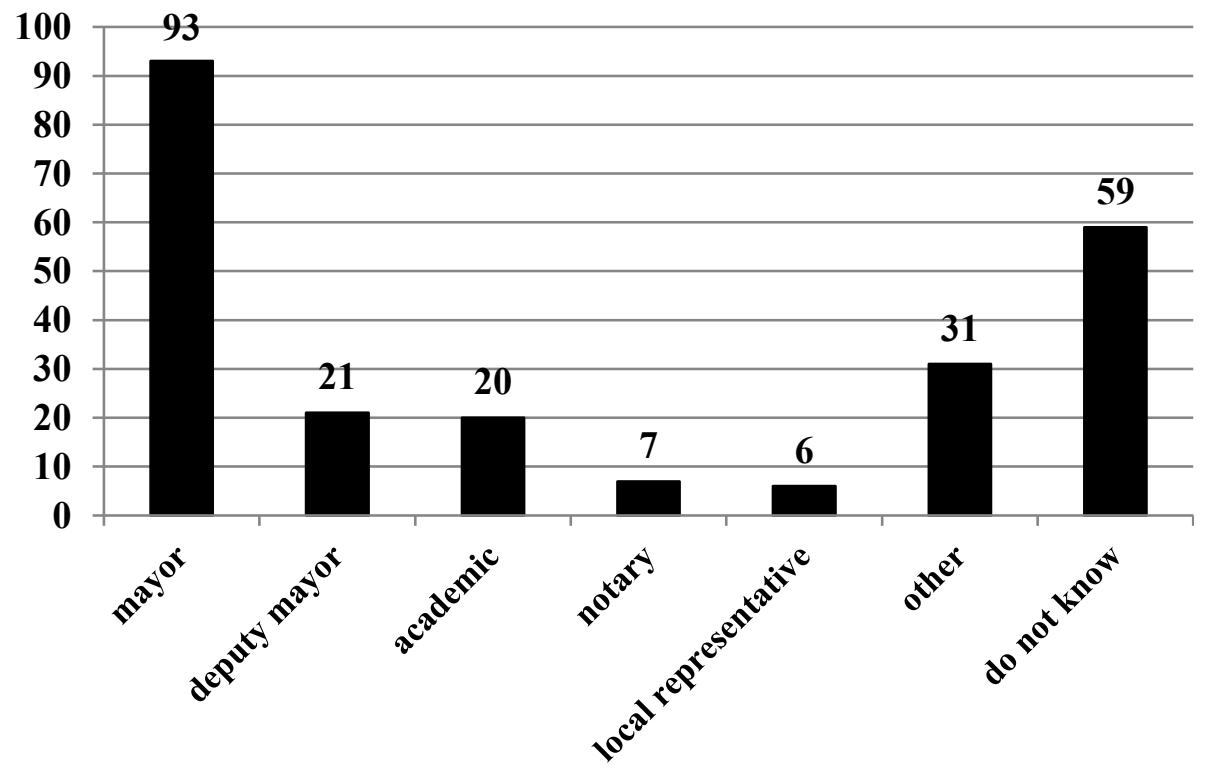

Figure 5. Who should be asked about the important issues related to village? (capita)

Source: own editing based on questionnaire survey, 2017

I also asked the villagers to make a list of people they talk to regularly. It was surprising that there were only rarely overlaps among answers. That means there were only a few people who were mentioned by two-three respondents. This indicates that there is not a person who would be in the center of the community, who could be an informal local initiator or leader. Most of the villagers talk only with their direct neighbours and relatives regularly.

The last studied component of social capital was civil social activity, which can be considered quite low at the settlement. It was found that only one-fourth $(24 \%)$ of the population was regularly engaged in some kind of voluntary services. Most of them supported some annually organized local community programmes, where some of them have cooked or baked, while others packed or cleaned the site, etc. Less people did regularly voluntary work (e.g. participated in the maintenance and decoration of church, in renewing and building community buildings or in waste collecting initiatives, etc.). Some other people mentioned that they helped their old relatives, friends, or engaged in free distribution of meals or donated blood. 
The other fundamental component of social activity is the membership in social organizations. Although the level of volunteering is quite low, almost a quarter of the respondents $(22 \%)$ were a member at least in one social organization. However, later it became light that most of them were only passive member of these organizations.

During our research 12 social organizations registered in Bátya village (Table 2). Most of the organizations provide cultural (e.g. Bátyai Fokhagymások Hagyományőrző, Gasztronómiai és Kulturális' Association, 'Bátyai Hagyományőrző és Nemzetiségi' Association, 'Bátyai Katolikus Olvasókör', 'Danúbia Ifjúsági Fúvószenekar' and 'Vodencia Horvát Nemzetiségi Táncegyüttes') or sport activities ('Bátyai Sport' Association, 'Bátyai Sporthorgász' Association and 'VARAJTI Hagyományőrző Íjász Sport' Association).

Table 2. Social organizations in Bátya village

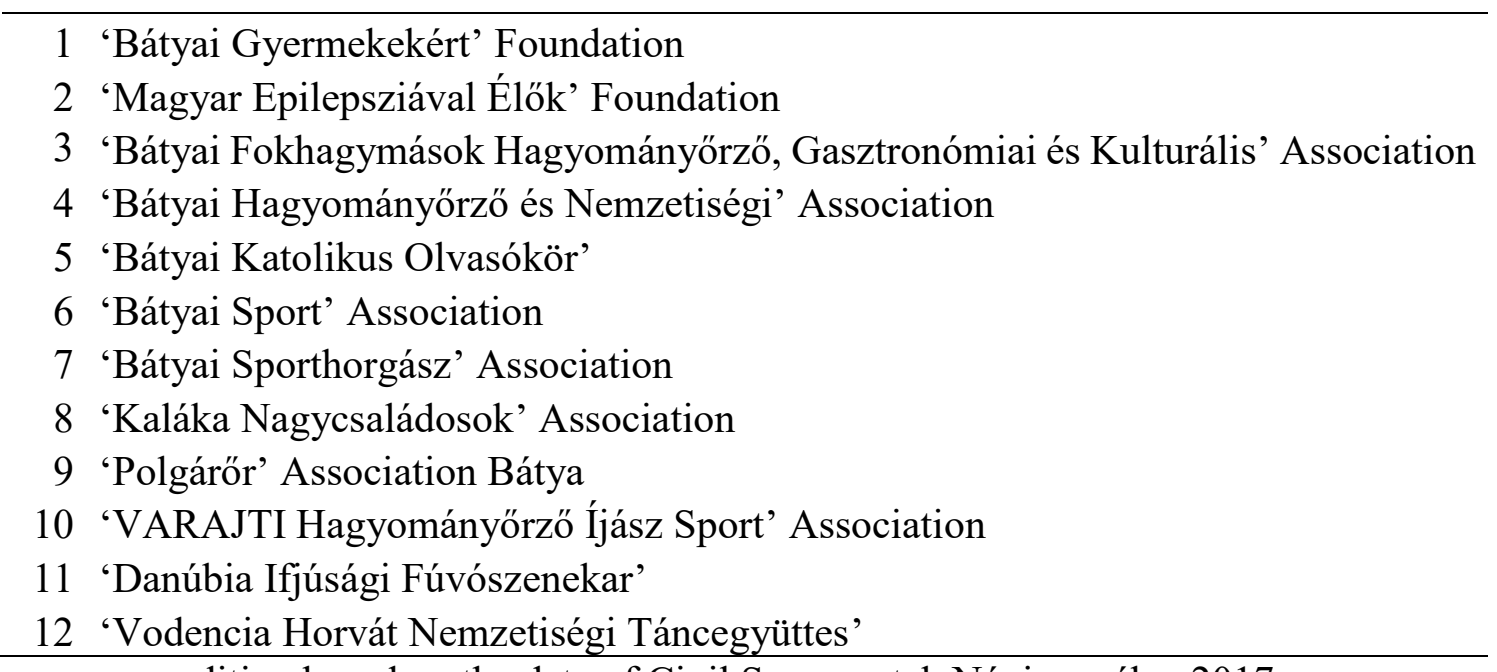
Source: own editing based on the data of Civil Szervezetek Névjegyzéke, 2017

\section{Conclusions and Recommendations}

The study has focused on the examination of the social capital which has a crucial role in smart development. First, the relation between social capital and smart communities was expounded. After that the four approaches to examine social capital were presented and then its main benefits were summarized. It can be concluded social capital has a vital role in both sustainable development.

A complex definition was demonstrated in the Introduction chapter, according to which social capital is a mixture of relations, trust, civil social activity and norms regulating social behaviour. The first three components of social capital were examined in this paper, namely the trust level, the relations among local people and the social activity. A special method based on primary and secondary data collection was demonstrated to measure the social capital in a small rural village, called Bátya.

A significant difference was found between the two forms of trust, general and strategic trust in Bátya village. The general trust felt towards foreign people based on empathy has quite unfavourable values. Although Hungary is among the countries having low level of general trust, these results are even much worse than in other Hungarian settlements took part in the research of Tárki in 2009. I revealed that the local community was separated into two groups on the basis of supporting the current or the previous mayor and there were many social and political conflicts between these groups. 
On the other hand, the situation in case of strategic trust felt towards family members and friends was much more favourable. Most of the inhabitants trusted both in their relatives, and their friends, and so they can easier go through difficulties by social support. It is typical that if is a low level of the general trust can experienced in a community, the strategic trust is high, since people can trust only in people they know well and understand.

It can be concluded that the trust in institutions similarly to general trust is quite weak. The institutional trust was examined by the question whose opinion should be taken into account concerning village issues. As I expected, the mayor and deputy mayor were most often mentioned. However, they were not indicated as many times as in in my previous researches in other Hungarian rural settlements. Moreover, the proportion of those who could not mention anybody whose view should be taken into account was quite high (25\%).

Concerning the third examined component of social capital, the civil social activity, I found that it was also quite low in Bátya village. Less than one-fourth of population did some voluntary work regularly and even less respondents were member at least in one civil social organization.

In the light of all the foregoing, it can be concluded that there is a medium strong social capital in Bátya villages. A special emphasis should be put on the enhancement of trust in the future. Building up trust takes a lot of time, but it could be accelerated by increasing the number of personal meeting. More attention should be given to the introduction of advantages and possibilities of membership in local social organizations and volunteer works. Moreover, the awareness of social organizations should be raised, too. So the social participation and activity might be also increased in long term.

\section{Acknowledgement}

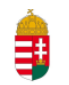

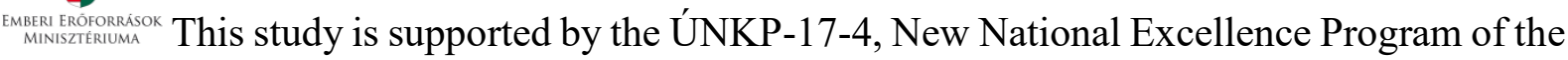
Ministry of Human Capacities.

\section{References}

1. Áldorfai, Gy. - Czabadai, L. - Topa, Z. (2016): A methodology for the foundation of a CLLD programme. In: L. Mura, M. Bumbalová, M. Gubáňová (eds.) (2016): Sustainability of Rural Areas in Practice Conference, 2015.12.03-2015.12.04. Nitra: Slovak University of Agriculture, pp. 103-110.

2. Bourdieu, P. (1986): The forms of capital. In: Angelus, R. (eds.) (1997): A társadalmi rétegződés komponensei. Új Mandátum, Budapest, Hungary, pp. 156-177.

3. Coleman, J.S. (1988): Social Capital in the Creation of Human Capital. In: The American Journal of Sociology, 94 (Supplement), pp. 95-120.

4. Fukuyama, F. (2002): Social Capital and Development: The Coming Agenda. In: SAIS Review, 22 (1), pp. 23-37.

5. Fukuyama, F. (2001): Social capital, civil society and development. In: Third World Quaterly, 22 (1), pp. 7-20.

6. Fukuyama, F. (1995): Social Capital and the Global Economy: A Redrawn Map of the World. In: Foreign Affairs, 74 (5), pp. 89-103.

7. Füzér, K. - Gerő, M. - Sik, E. - Zongor, G. (2005): A társadalmi töke növelésének lehetőségei fejlesztéspolitikai eszközökkel. Fejlesztéspolitika társadalmi hatásai 4. TÁRKI, Budapest. 
8. Gerencsér, I. - Áldorfai, Gy. (2017): Közösségi szerepvállalás helyi fejlesztési stratégia kialakításában. In: Studia Mundi - Economica, 4 (1), pp. 26-34.

9. Gurstein, M. (2014): Smart Cities vs. Smart Communities: Empowering Citizens not Market Economics. In: Gurstein's Community Informatics, 10(3), n.p.

10. Havasi, V. (2009): Az értékrend és az életminőség összefüggései. PhD thesis, Debreceni Egyetem, Közgazdaságtudományi Doktori Iskola, Debrecen.

11. Kis, K. (2006a): A társadalmi tőke, mint a társadalmi és gazdasági folyamatokat befolyásoló erőforrás. In: Agrártudományi Közlemények, 2006/20. különszám, pp. 6973.

12. Kis, K. (2006b): Partnerség és társadalmi tőke a vidékfejlesztésben. In: Parola, (2-3), pp. 28-31.

13. Kulcsár, L. (2006): A vidékfejlesztés alapjai. Szent István University, Gödöllő.

14. Kuti, É. (1996): A nonprofit szervezetek szerepe a kilencvenes évek magyar társadalmában és gazdaságában (The role of non-profit organizations in the society and economy of Hungary in the 1990s). Közgazdasági Szemle, 1996/1, pp. 18-30.

15. Lee, J. - Árnason, A. - Nightingale, A. - Shucksmith, M. (2005): Networking: Social Capital and Identities in European Rural Development. In: Sociologia Ruralis, 45 (4), pp. 269-283.

16. Nárai, M. (2008): A nonprofit szervezetek helye és szerepe a helyi társadalmak életében - A nyugat-dunántúli nonprofit szektor helyzetfeltárása (The role of nonprofit organizations in local societies). ELTE Szociológiai Doktori Iskola, Budapest.

17. Nárai, M. (2004): A civil szervezetek szerepe és jelentősége az egyének, közösségek, illetve a társadalom számára. Education, 2004/4, pp. 616-634.

18. Oláh, I. - Nagy, A. - Ökrös, I. (2012): The role of local communities in the local economic development. Annals of the Polish Association of Agricultural and Agribusiness Economists, 14 (6), pp. 196-199.

19. Putnam, R. (2000): Bowling Alone. The Collapse and Revival of American Community. Simon \& Schuster, New York, 541p.

20. Putnam, R. D. (1995): Bowling Alone: America's Declining Social Capital. In: Journal of Democracy, 6 (1), pp. 65-78.

21. Putnam, R. D. (1993): The Prosperous Community: Social Capital and Public Life. In: The American Prospect, 13 (4), pp. 35-42.

22. Skrabski, Á. - Kopp, M. (2008): A bizalom, mint a társadalmi tőke központi jellemzője. In: Vigilia, 73 (10), pp. 722-730.

23. Reisinger A. (2012): Civil/nonprofit szervezetek a kohéziós politikában - elméleti alapok (Civil/non-profit organisations in the cohesion policy - theoretical background). Tér és társadalom, 26(1), pp. 41-65.

24. Ritter, K. (2014): Potential of the Social Economy in Development Policites - The Case of Africa. In: Gy. I. Neszmélyi (ed.) (2014): Socio-Economic and Regional Processes in the Developing Countries, pp. 176-186.

25. Stratigea, A. (2012): The concept of 'smart cities'. Towards community development? In: NETCOM, 26 (3-4), pp. 375-388.

26. Szakál, Gy. (2004): A társadalmi tőke hatása az oktatásra, egészségre és a civil szférára. In: Szakál, Gy. - Gergely, A. (szerk.): Társadalmi tőke, karrieresélyek, viselkedésminták. MTA, Budapest, pp. 6-20.

27. Tóth, T. - Jóna, Gy. (2012): Concepts of the Territorial Capital. In: SELYE ESTUDIES, pp. 1-15. At: http://selyeuni.sk/gtk/e-studies/en.html Downloaded: 19.08.2017.

28. Tóth, T. - Káposzta, J. (2013): Tervezési módszerek és eljárások a vidékfejlesztésben. Debreceni Egyetem Gazdálkodástudományok Centruma, Debrecen. 


\section{Other sources}

1. Civil Szervezetek Névjegyzéke, 2017

2. Hungarian Central Statistical Office (HCSO) - Census, 2011

3. Hungarian Central Statistical Office (HCSO) - TSTAR, 2015 